\title{
Halococcus qingdaonensis sp. nov., a halophilic archaeon isolated from a crude sea-salt sample
}

Correspondence Guang-qin Guo gqguo@|zu.edu.cn

\author{
Qian-fu Wang, ${ }^{1} \dagger$ Wei Li, ${ }^{1} \dagger$ Hai Yang, ${ }^{1}$ Yan-li Liu, ${ }^{1}$ Hai-hua Cao, ${ }^{1}$ \\ Marion Dornmayr-Pfaffenhuemer, ${ }^{2}$ Helga Stan-Lotter ${ }^{2}$ \\ and Guang-qin Guo ${ }^{1}$ \\ ${ }^{1}$ Institute of Cell Biology, School of Life Sciences, Lanzhou University, Lanzhou 730000, \\ P. R. China \\ ${ }^{2}$ Fachbereich Molekulare Biologie, Abt. Mikrobiologie, Billrothstrasse 11, A-5020 Salzburg, \\ Austria
}

\begin{abstract}
A Gram-negative, extremely halophilic, coccoid archaeal strain, $\mathrm{CM}^{\top}$, was isolated from a crude sea-salt sample collected near Qingdao, China. The organism grew optimally at $35-40{ }^{\circ} \mathrm{C}$ and $\mathrm{pH} 6.0$ in the presence of $20 \%(\mathrm{w} / \mathrm{v}) \mathrm{NaCl}$. Its colonies were red in colour and it could use glucose as a sole carbon source for growth. The $16 \mathrm{~S}$ rRNA gene sequence of $\mathrm{CM}^{\top}$ was most closely related to those of Halococcus species. Its pattern of antibiotic susceptibility was similar to those of other described Halococcus species. Biochemical tests revealed no sign of $\mathrm{H}_{2} \mathrm{~S}$ production or gelatin liquefaction. The main polar lipids of strain $\mathrm{CM}^{\top}$ were phosphatidylglycerol, phosphatidylglycerol methylphosphate and sulfated diglycosyl diether. No phosphatidylglycerol sulfate was present. The DNA G $+\mathrm{C}$ content of strain $\mathrm{CM}^{\top}{ }^{\top}$ was $61.2 \mathrm{~mol} \%$ and it gave DNA-DNA reassociation values of 33.7, 57.1 and $29.6 \%$, respectively, with Halococcus salifodinae DSM $8989^{\top}$, Halococcus dombrowskii DSM $14522^{\top}$ and Halococcus morrhuae ATCC $17082^{\top}$. Based on its morphological and chemotaxonomic properties and phylogenetic analysis of 16S rRNA gene sequence data, we propose that $\mathrm{CM}^{\top}$ should be classified within a novel species, Halococcus qingdaonensis sp. nov., with strain $\mathrm{CM}^{\top}$ ( $=$ CGMCC $\left.1.4243^{\top}=\mathrm{JCM} 13587^{\top}\right)$ as the type strain.
\end{abstract}

The extremely halophilic bacteria are defined as microorganisms that grow best in media containing 2.5-5.2 M (saturated) $\mathrm{NaCl}$ (Kushner \& Kamekura, 1988) and include members of both the Archaea and the Bacteria, among them aerobic halophilic archaea that require at least $12 \%$ (2 M) $\mathrm{NaCl}$ for growth, which are classified within the family Halobacteriaceae. In recent years, many halobacterial strains have been isolated and described within novel species. The number of genera within this family has increased to 22 (http://www.bacterio.cict.fr/classifgenerafamilies.html\# Halobacteriaceae). Halococcus was the second genus after Halobacterium to be classified within the family Halobacteriaceae (Skerman et al., 1980). Currently, there are five recognized species in this genus (Larsen, 1989; Stan-Lotter et al., 2002; Garrity et al., 2004; Goh et al., 2006). Here we report the isolation and taxonomic analysis of a strain representing a novel Halococcus species from a crude sea-salt sample collected near Qingdao in eastern China.

†These authors contributed equally to this work.

The GenBank/EMBL/DDBJ accession number for the 16S rRNA gene sequence of strain $C M 5^{\top}$ is $A Y 243109$.
CM medium (Seghal \& Gibbons, 1960) with $20 \% \mathrm{NaCl}$ at $\mathrm{pH} 7.0$ was used for halobacterial enrichment and growth. The sample was firstly inoculated in liquid medium and cultured on a shaker (120 r.p.m.) at $37^{\circ} \mathrm{C}$ in the dark until turbid, and then streaked onto solid medium to produce single colonies. Streaking was repeated several times to obtain pure single colonies. Purified strains were cultured and maintained in liquid or on solid ATCC213 medium with $18 \% \mathrm{NaCl}$ at $\mathrm{pH} 6.0$ in the dark.

Seven days after being cultured in liquid medium, living cells were observed under a phase-contrast microscope. Gram staining was performed according to Dussault (1955) and electron microscopy was used to reveal the detailed morphology. Samples were fixed in $5 \%(\mathrm{v} / \mathrm{v})$ glutaraldehyde (in $0.2 \mathrm{M}$ phosphate buffer, $\mathrm{pH}$ 7.2) for $2 \mathrm{~h}$ on ice, washed three times in phosphate buffer and subsequently post-fixed for $1 \mathrm{~h}$ in $2 \%$ osmium tetroxide. The pellet was dehydrated with propanol and embedded in resin. Embedding was done according to the protocol of Spurr (1969). Ultrathin sections were prepared with an LKB ultramicrotome and double stained with uranyl acetate and lead citrate. After air-drying, the samples were examined with an electron microscope (JEM-1230). For negative staining, liquid culture of cells at 
the exponential growth phase was allowed to dry on the grids and stained with $2 \%$ phosphotungstic acid.

Halobacterial growth was determined by measuring optical density at $460 \mathrm{~nm}$ at intervals during growth of the liquid culture. The effect of different concentrations of $\mathrm{NaCl}$ on growth of strain $\mathrm{CM}^{\mathrm{T}}$ was tested in liquid ATCC213 medium. After 7 days of incubation, the optical density at $460 \mathrm{~nm}$ was measured. Susceptibility of $\mathrm{CM}^{\mathrm{T}}$ to the antibiotics ampicillin, tetracycline, hygromycin, kanamycin, streptomycin, rifampicin, bacitracin, penicillin, chloramphenicol, neomycin and erythromycin (all from Sigma) was tested by placing $6 \mathrm{~mm}$ diameter discs containing $20 \mu \mathrm{g}$ antibiotic on agar plates followed by 7 days incubation at $37^{\circ} \mathrm{C}$. Sensitivity was deemed strong when the diameter of the zone of inhibition was $>15 \mathrm{~mm}$ (i.e. $4.5 \mathrm{~mm}$ beyond the antibiotic disc) and moderate between 6 and $15 \mathrm{~mm}$ (1-4.5 $\mathrm{mm}$ beyond the antibiotic disc).

Physiological and biochemical tests were performed according to Gibbons (1974) and Tian et al. (1997). Anaerobic growth of $\mathrm{CM}^{\mathrm{T}}$ with nitrate as the electron acceptor was tested as described by Mancinelli \& Hochstein (1986) and growth with DMSO and fermentation of L-arginine as the electron acceptor were tested as described by Oren et al. (1997) and Oren \& Trüper (1990), in closed tubes fully filled with the growth medium and held in the dark for more than 1 month which were then compared with growth on media without the test compounds.

Cells for pigment determination were collected by centrifugation and washed twice with $25 \% \mathrm{NaCl}$. They were extracted with a $1: 1(\mathrm{v} / \mathrm{v})$ mixture of acetone and methanol for $1 \mathrm{~h}$. After centrifugation, the absorption spectrum of the supernatant was determined. Polar lipids were extracted from $300 \mathrm{mg}$ freeze-dried cells using the method described by Tindall (1990). They were further purified by extraction with chloroform/methanol $/ 0.3 \% \mathrm{NaCl}(1: 2: 0.8$, by vol.) and separated by two-dimensional silica-gel TLC (Ross et al., 1985). Polar-lipid extracts were spotted onto the corner of a $10 \times 10 \mathrm{~cm}$ thin-layer silica-gel plate $\left(60 \mathrm{~F}_{254} ;\right.$ Merck $)$. The first direction was developed in chloroform/methanol/water $(65: 25: 4$, by vol.) and the second in chloroform/ methanol/acetic acid/water $(80: 12: 15: 4$, by vol.). Total lipids and specific functional groups were detected using phosphomolybdic acid, molybdenum blue, $\alpha$-naphthol and Bial's reagent (orcinol ferric chloride spray reagent) (StanLotter et al., 1999, 2002). The equivalence of spots was determined by co-chromatography of extracts of known haloarchaea in two dimensions and by comparison with published data.

The DNA G $+\mathrm{C}$ content of strain $\mathrm{CM} 5^{\mathrm{T}}$ was determined using the thermal denaturation method of Marmur \& Doty (1962) with Escherichia coli JM105 as a control. We used the optical renaturation method (De Ley et al., 1970; Huß et al., 1983; Jahnke, 1992) to perform DNA-DNA hybridization experiments. The three most closely related strains, Halococcus dombrowskii DSM $14522^{\mathrm{T}}$, Halococcus morrhuae ATCC $17082^{\mathrm{T}}$ and Halococcus salifodinae DSM $8989^{\mathrm{T}}$, were used as reference strains.

PCR amplification of 16S rRNA genes was performed according to Wang et al. (2000) after total DNA extraction by using primers $5^{\prime}$-ATTCCGGTTGATCCTGCCGGA-3' (primer 1; positions 6-25, according to E. coli numbering) and $5^{\prime}$-AGGAGGTGATCCAAGCCGCAG-3' (primer 2; positions $1540-1521)$ with 36 cycles of denaturing $\left(94^{\circ} \mathrm{C}\right.$, $1 \mathrm{~min})$, annealing $\left(52^{\circ} \mathrm{C}, 1 \mathrm{~min}\right)$ and extension $\left(72^{\circ} \mathrm{C}\right.$, $3 \mathrm{~min})$. The PCR product was ligated to the T-vector and transformed into E. coli DH10 for purification and sequencing. Sequences used for comparison with the $16 \mathrm{~S}$ rRNA gene sequence from strain $\mathrm{CM} 5^{\mathrm{T}}$ were obtained from GenBank by using the BLASTN program and the sequence was aligned with closely related $16 \mathrm{~S}$ rRNA gene sequences with CLUSTAL X software program version 1.83 (Thompson et al., 1997). The phylogenetic tree was constructed by the neighbour-joining method (Saitou \& Nei, 1987) in MEGA program version 3.1 (Kumar et al., 2001, 2004). Confidence values of branches of the phylogenetic tree were determined using bootstrap analyses (Felsenstein, 1985) based on 1000 resamplings.

Cells of strain $\mathrm{CM}^{\mathrm{T}}$ were coccoids, $0.6-1.5 \mu \mathrm{m}$ in diameter (Fig. 1). They were non-motile and often arranged in doublets or tetrads; they stained Gram-negative and did not lyse in distilled water. The colonies were red in colour, wet and smooth-surfaced with clear edges and reached $0.5 \mathrm{~mm}$ in size after 7 days of culture at $37^{\circ} \mathrm{C}$ on ATCC213 medium. Strain $\mathrm{CM}^{\mathrm{T}}$ could grow at $\mathrm{pH} 4.0-9.0$, with optimal
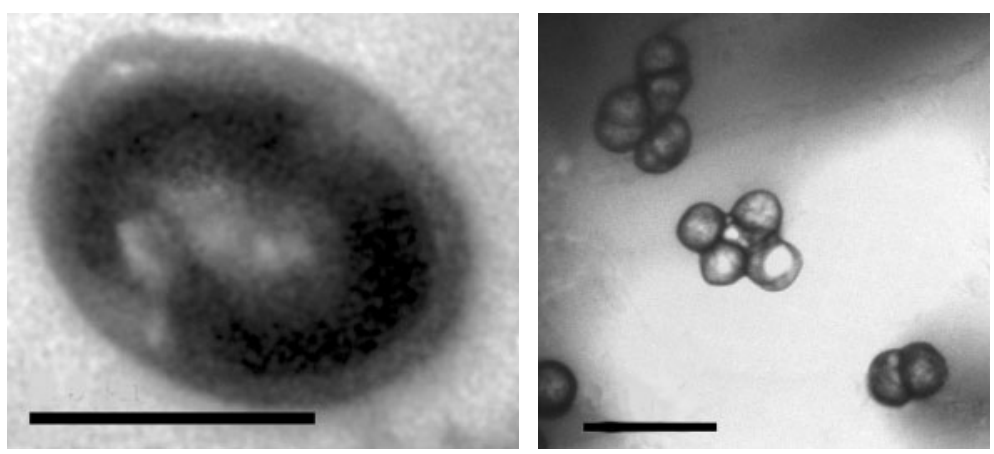

Fig. 1. Transmission electron micrographs of strain $\mathrm{CM}^{\top}$. Left, ultrathin section (bar, $0.5 \mu \mathrm{m})$; right, negative staining showing doublet/tetrad arrangements (bar, $2 \mu \mathrm{m}$ ). 


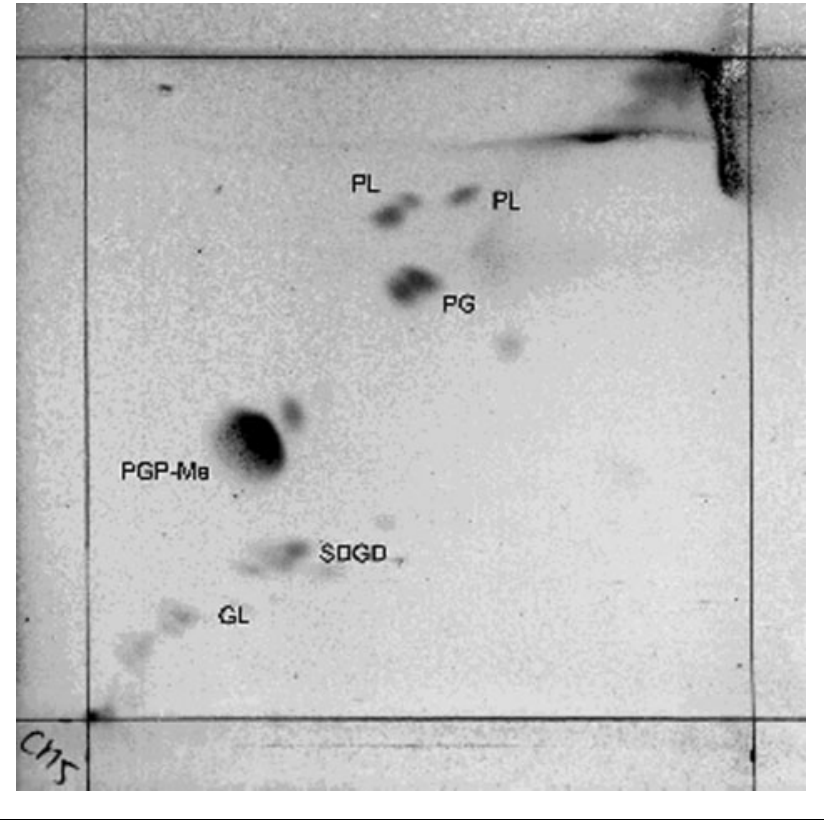

Fig. 2. Polar lipid pattern of strain $C M 5^{\top}$. PG, Glycerol diether of phosphatidylglycerol; PGP-Me, glycerol diether of phosphatidylglycerol methylphosphate; SDGD, sulfated diglycosyl diether; $\mathrm{PL}$, unidentified phospholipid; GL, unidentified glycolipid.

growth at $\mathrm{pH}$ 6.0. It required at least $10 \% \mathrm{NaCl}$ for growth and $18 \%$ was the optimum. The optimal $\mathrm{Mg}^{2+}$ concentration was $40 \mathrm{mM}$. The permissive temperature for growth was between 26 and $45^{\circ} \mathrm{C}$, with optimum growth between 35 and $40{ }^{\circ} \mathrm{C}$.

Pigment determination revealed three absorbance spectrum peaks at 389, 495 and $527 \mathrm{~nm}$ for $\mathrm{CM}^{\mathrm{T}}$, which are characteristic of carotenoids in extremely halophilic archaea. Two-dimensional TLC analysis of the polar lipids in strain $\mathrm{CM}^{\mathrm{T}}$ (Fig. 2) as well as the three reference strains revealed the presence of $\mathrm{C}_{20} \mathrm{C}_{20}$ and $\mathrm{C}_{20} \mathrm{C}_{25}$ archaeal core lipids, which were detected by double spots. Glycerol diethers of phosphatidylglycerol and phosphatidylglycerol methylphosphate and sulfated diglycosyl diether were present in strain $\mathrm{CM}^{\mathrm{T}}$; no phosphatidylglycerol sulfate was present. These patterns were similar to those of $\mathrm{Hcc}$. morrhuae DSM $1307^{\mathrm{T}}$, Hcc. salifodinae DSM $8989^{\mathrm{T}}$ and $H c c$. dombrowskii DSM $14522^{\mathrm{T}}$. Two unknown phospholipids and one unknown glycolipid were present in strain $\mathrm{CM}^{\mathrm{T}}$. The overall phospholipid pattern of strain $\mathrm{CM}^{\mathrm{T}}$ was characteristic of members of the genus Halococcus (Ross et al., 1985; Wainø et al., 2000).

Growth of strain $\mathrm{CM}^{\mathrm{T}}$ was strongly inhibited by the antibiotics rifampicin and bacitracin and moderately inhibited by neomycin and chloramphenicol. No inhibition was observed when the strain was grown in the presence of erythromycin, ampicillin, kanamycin, streptomycin, tetracycline, hygromycin or penicillin. The susceptibility pattern of strain $\mathrm{CM} 5^{\mathrm{T}}$ was similar to those of Hcc. dombrowskii DSM $14522^{\mathrm{T}}$ and Hcc. morrhuae DSM $1307^{\mathrm{T}}$ (determined in our experiments), except that the latter strains were moderately susceptible to erythromycin, similar to the result described by Stan-Lotter et al. (2002).

Strain $\mathrm{CM} 5^{\mathrm{T}}$ was distinct from other Halococcus species in a number of biochemical properties (Table 1). Unlike Hcc. morrhuae and Halococcus saccharolyticus, it did not produce $\mathrm{H}_{2} \mathrm{~S}$ and was negative for gelatin hydrolysis. Nitrate reduction was not detected with $\mathrm{CM}^{\mathrm{T}}$. Indole but not organic acids could be produced from sugars. It had catalase, but no oxidase, arginine dihydrolase or urease activity. It could use glucose, galactose, sucrose, inositol, fructose and rhamnose, but not sorbitol, cellobiose, mannitol, dextran or

Table 1. Characteristics that differentiate strain $\mathrm{CM} 5^{\top}$ from type strains of other Halococcus species

Strains: 1, strain $\mathrm{CM}^{\mathrm{T}}$; 2, Hcc. morrhuae ATCC $17082^{\mathrm{T}}$; 3, Hcc. dombrowskii $\mathrm{H} 4^{\mathrm{T}}$; 4, Hcc. salifodinae DSM $8989^{\mathrm{T}}$ (data in columns $1-4$ determined in this study unless indicated); 5, Hcc. saccharolyticus ATCC 49257 (data from Montero et al., 1989); 6, Hcc. hamelinensis $100 \mathrm{A6}^{\mathrm{T}}$ (data from Goh et al., 2006). +, Positive reaction or growth; -, no reaction or growth; V, variable; ND, no data available.

\begin{tabular}{|c|c|c|c|c|c|c|}
\hline Characteristic & 1 & 2 & 3 & 4 & 5 & 6 \\
\hline Optimum $\mathrm{NaCl}$ concentration $(\% \mathrm{w} / \mathrm{v})$ & 18 & $20-30^{a_{\star}}$ & $20-30^{b}$ & $20-30^{c}$ & $20-30$ & 15 \\
\hline $\mathrm{pH}$ range for growth & $4.0-9.0$ & $5.5-8.0^{a}$ & $5.2-8.0^{b}$ & $6.8-9.5^{c}$ & $6.0-8.0$ & $4.0-9.0$ \\
\hline Oxidase & - & $+{ }^{a}$ & + & + & + & - \\
\hline Nitrate reduction & - & + & + & + & + & + \\
\hline Starch hydrolysis & + & - & - & - & - & + \\
\hline Gelatin liquefaction & - & $+{ }^{a}$ & + & + & $\mathrm{V}$ & - \\
\hline Tween 80 hydrolysis & - & $+{ }^{a}$ & - & + & - & ND \\
\hline \multicolumn{7}{|l|}{ Use of carbohydrates: } \\
\hline Glucose & + & - & - & + & $\mathrm{ND}$ & + \\
\hline Lactose & - & - & - & + & + & - \\
\hline
\end{tabular}

${ }^{\star}$ Data taken from following references: $a$, Grant \& Larsen (1989); b, Stan-Lotter et al. (2002); c, Denner et al. (1994). 
lactose, as sole carbon sources. $\mathrm{CM} 5^{\mathrm{T}}$ could not grow anaerobically in the presence of nitrate or DMSO or by fermenting L-arginine.

The $\mathrm{G}+\mathrm{C}$ content of strain $\mathrm{CM} 5^{\mathrm{T}}$ was $61.2 \mathrm{~mol} \%$, similar to the values determined for Hcc. morrhuae $[62.3 \mathrm{~mol} \%$ (this study); 61-66 mol\% (Larsen, 1989)], Hcc. dombrowskii (61.3 mol\%; Stan-Lotter et al., 2002) and Hcc. salifodinae [62.7 mol\% (this study); $62 \pm 1 \mathrm{~mol} \%$ (Denner et al., 1994)]. DNA-DNA reassociation values between strain $\mathrm{CM}^{\mathrm{T}}$ and related type strains were $33.65 \%$ with $H c c$. salifodinae DSM $8989^{\mathrm{T}}, 57.1 \%$ with Hcc. dombrowskii DSM $14522^{\mathrm{T}}$ and $29.6 \%$ with Hcc. morrhuae ATCC $17082^{\mathrm{T}}$ (each repeated three times). Levels of $70 \%$ or more relatedness can be considered indicative of species levels of similarity (Gutierrez et al., 1989, 1990); hence, strain $\mathrm{CM}^{\mathrm{T}}$ represented a novel species of the genus Halococcus.

The full sequence (1476 bases) of the 16S rRNA gene of strain $\mathrm{CM} 5^{\mathrm{T}}$ was determined. Phylogenetic analysis of strain $\mathrm{CM}^{\mathrm{T}}$ using $16 \mathrm{~S}$ rRNA gene sequences showed high similarity to Hcc. morrhuae ATCC $17082^{\mathrm{T}}(99.3 \%)$ and Hcc. dombrowskii $\mathrm{H}_{4}^{\mathrm{T}}$ (99.2 \%), but less to Hcc. salifodinae DSM $8989^{\mathrm{T}}(94 \%)$, Hcc. saccharolyticus ATCC $49257^{\mathrm{T}}$ $(93.8 \%)$ and Halococcus hamelinensis $100 \mathrm{A6}^{\mathrm{T}}$ (93.2\%). Phylogenetic analysis based on neighbour-joining showed that strain $\mathrm{CM} 5^{\mathrm{T}}$ forms a branch within the Hcc. morrhuae lineage (Fig. 3). The genus Halococcus appears to contain at least two lineages on the basis of $16 \mathrm{~S}$ rRNA gene sequence data: one contains Hcc. salifodinae and Hcc. saccharolyticus, while the other consists of Hcc. morrhuae and other coccoid strains (Stan-Lotter et al., 2002).

On the basis of its $16 \mathrm{~S}$ rRNA gene sequence, $\mathrm{G}+\mathrm{C}$ content, polar-lipid content, antibiotic sensitivity and other characteristics, the coccoid strain $\mathrm{CM}^{\mathrm{T}}$ was identified as being a halophilic archaeon of the genus Halococcus. Unlike Hcc. morrhuae and Hcc. dombrowskii, $\mathrm{CM}^{\mathrm{T}}$ produced no $\mathrm{H}_{2} \mathrm{~S}$, was not sensitive to tetracycline and could use glucose as a sole carbon source. Hcc. dombrowskii requires at least $15 \%$ $\mathrm{NaCl}$ for growth, and the optimal concentration is $25-30 \%$ (Stan-Lotter et al., 2002), whereas the minimal and optimal

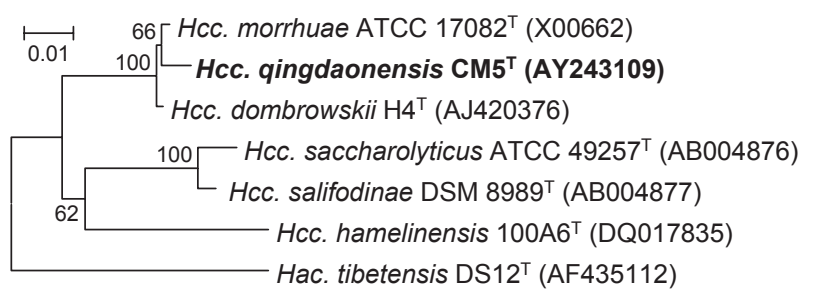

Fig. 3. Phylogenetic relationships of strain $\mathrm{CM}^{\top}$ and other related taxa, constructed using neighbour-joining method and based on 16S rRNA gene sequences. Halalkalicoccus tibetensis DS12 ${ }^{\top}$ was used as an outgroup. Bootstrap values are shown as percentages of 1000 replicates. Bar, 0.01 changes per nucleotide position.
$\mathrm{NaCl}$ concentrations for growth of strain $\mathrm{CM}^{\mathrm{T}}$ were 10 and $18-20 \%$, respectively. Strain $\mathrm{CM}^{\mathrm{T}}$ differed from $\mathrm{Hcc}$. dombrowskii and Hcc. morrhuae with respect to its cellular morphology and arrangement, DNA-DNA reassociation value, susceptibility to some antibiotics and usage of carbohydrates. The values of less than $70 \%$ DNA-DNA reassociation between $\mathrm{CM}^{\mathrm{T}}$ and $\mathrm{Hcc}$. morrhuae ATCC $17082^{\mathrm{T}}(29.6 \%)$ and Hcc. dombrowskii DSM $14522^{\mathrm{T}}$ $(57.1 \%)$ also support the suggestion to designate $\mathrm{CM}^{\mathrm{T}}$ as representing a novel species. In conclusion, we describe $\mathrm{CM} 5^{\mathrm{T}}$ as the type strain of a novel species, for which we propose the name Halococcus qingdaonensis sp. nov.

\section{Description of Halococcus qingdaonensis sp. nov.}

Halococcus qingdaonensis (qing.dao.nen'sis. N.L. masc. adj. qingdaonensis pertaining to Qingdao, from where the type strain was isolated).

Aerobic, Gram-negative, non-motile cocci, $0.6-1.5 \mu \mathrm{m}$ in diameter, often occurring as doublets or tetrads. Colonies are red in colour, wet and smooth-surfaced with clear edges, reaching $0.5 \mathrm{~mm}$ in size after 7 days of cultivation at $37^{\circ} \mathrm{C}$. The optimum temperature for growth is $35-40^{\circ} \mathrm{C}$; the $\mathrm{pH}$ range for growth is 4.0-9.0, with optimum growth at $\mathrm{pH}$ 6.0. It requires at least $10 \% \mathrm{NaCl}$ for growth and $18 \%$ is the optimum. No lysis is observed in distilled water. The optimal $\mathrm{Mg}^{2+}$ concentration is $40 \mathrm{mM}$. Catalase reaction is positive. It has no oxidase, arginine dihydrolase or urease activity. Gelatin is not liquefied. The reaction for Tween 80 is negative. Glucose can be used as the sole carbon source for growth. The type strain is susceptible to rifampicin and bacitracin, moderately susceptible to neomycin and chloramphenicol and resistant to erythromycin, ampicillin, kanamycin, streptomycin, tetracycline, hygromycin and penicillin. Main polar lipids are phosphatidylglycerol, phosphatidylglycerol methylphosphate, sulfated diglycosyl diether. No phosphatidylglycerol sulfate is present. The $\mathrm{G}+\mathrm{C}$ content of the type strain is $61.2 \mathrm{~mol} \%$.

The type strain, $\mathrm{CM}^{\mathrm{T}}\left(=\mathrm{CGMCC} 1.4243^{\mathrm{T}}=\mathrm{JCM} 13587^{\mathrm{T}}\right)$, was isolated from a crude sea-salt sample collected near Qingdao in eastern China.

\section{Acknowledgements}

This work was supported by the National Science Foundation of China (NSFC, 3027) and the Austrian Science Foundation (FWF), P18256. We thank Mr Bing Pi for his help in the phylogenetic analysis. We are indebted to Dr Wen-jun Li, Yunan University, China, and Professor Pei-jin Zhou, Institute of Microbiology, CAS, for their excellent technical assistance in determination of $\mathrm{G}+\mathrm{C}$ content and DNA-DNA hybridization experiments.

\section{References}

De Ley, L., Cattoir, H. \& Reynaerts, A. (1970). The quantitative measurement of DNA hybridization from renaturation rates. Eur J Biochem 12, 133-142. 
Denner, E. B. M., McGenity, T. J., Busse, H.-J., Grant, W. D., Wanner, G. \& Stan-Lotter, H. (1994). Halococcus salifodinae sp. nov., an archaeal isolate from an Austrian salt mine. Int J Syst Bacteriol 44, 774-780.

Dussault, H. P. (1955). An improved technique for staining red halophilic bacteria. J Bacteriol 70, 484-485.

Felsenstein, J. (1985). Confidence limits on phylogenies: an approach using the bootstrap. Evolution 39, 783-791.

Garrity, G. M., Bell, J. A. \& Lilburn, T. G. (2004). Taxonomic outline of the prokaryotes. In Bergey's Manual of Systematic Bacteriology, 2nd edn, release 5.0. New York: Springer. http://141.150.157.80/bergeysoutline/main.htm

Gibbons, N. E. (1974). Family V. Halobacteriaceae fam. nov. In Bergey's Manual of Determinative Bacteriology, 8th edn, pp. 269-273. Edited by R. G. Buchanan \& N. E. Gibbons. Baltimore: Williams \& Wilkins.

Goh, F., Leuko, S., Allen, M. A., Bowman, J. P., Kamekura, M., Neilan, B. A. \& Burns, B. P. (2006). Halococcus hamelinensis sp. nov., a novel halophilic archaeon isolated from stromatolites in Shark Bay, Australia. Int J Syst Evol Microbiol 56, 1323-1329.

Grant, W. D. \& Larsen, H. (1989). Group III. Extremely halophilic archaeobacteria. Order Halobacteriales ord. nov. In Bergey's Manual of Systematic Bacteriology, vol. 3, pp. 2216-2219. Edited by J. T. Staley, M. P. Bryant, N. Pfennig \& J. G. Holt. Baltimore: Williams \& Wilkins.

Gutierrez, M. C., Ventosa, A. \& Ruiz-Berraquero, F. (1989). DNADNA homology studies among strains of Haloferax and other halobacteria. Curr Microbiol 18, 253-256.

Gutierrez, M. C., Ventosa, A. \& Ruiz-Berraquero, F. (1990). Deoxyribonucleic acid relatedness among species of Haloarcula and other halobacteria. Biochem Cell Biol 68, 106-110.

Huß, V. A. R., Festl, H. \& Schleifer, K. H. (1983). Studies on the spectrophotometric determination of DNA hybridization from renaturation rates. Syst Appl Microbiol 4, 184-192.

Jahnke, K.-D. (1992). BASIC computer program for evaluation of spectroscopic DNA renaturation data from Gilford System 2600 spectrophotometer on a PC/XT/AT type personal computer. J Microbiol Methods 15, 621-627.

Kumar, S., Tamura, K., Jakobson, I.-B. \& Nei, M. (2001). MEGA2: molecular evolution analysis software. Bioinformatics 17, 1244-1245.

Kumar, S., Tamura, K., Jakobson, I.-B. \& Nei, M. (2004). MEGA3: integrated software for molecular evolutionary genetics analysis and sequence alignment. Brief Bioinform 5, 150-163.

Kushner, D. J. \& Kamekura, M. (1988). Physiology of halophilic eubacteria. In Halobacteria, vol. 1, pp. 109-140. Edited by F. Rodriguez-Valera. Boca Raton, FL: CRC Press.

Larsen, H. (1989). Genus IV. Halococcus Schoop 1935, 817 ${ }^{\mathrm{AL}}$. In Bergey's Manual of Systematic Bacteriology, vol. 3, pp. 2228-2230. Edited by J. T. Staley, M. P. Bryant, N. Pfennig \& J. G. Holt. Baltimore: Williams \& Wilkins.

Mancinelli, R. L. \& Hochstein, L. I. (1986). The occurrence of denitrification in extremely halophilic bacteria. FEMS Microbiol Lett $35,55-58$.
Marmur, J. \& Doty, P. (1962). Determination of the base composition of deoxyribonucleic acid from its denaturation temperature. $J \mathrm{Mol}$ Biol 5, 109-118.

Montero, C. G., Ventosa, A., Rodriguez-Valera, F., Kates, M., Moldoveanu, N. \& Ruiz-Berraquero, F. (1989). Halococcus saccharolyticus sp. nov., a new species of extremely halophilic nonalkaliphilic cocci. Syst Appl Microbiol 12, 167-171.

Oren, A. \& Trüper, H. G. (1990). Anaerobic growth of halophilic archaeobacteria by reduction of dimethylsulfoxide and trimethylamine N-oxide. FEMS Microbiol Lett 70, 33-36.

Oren, A., Ventosa, A. \& Grant, W. D. (1997). Proposed minimal standards for description of new taxa in the order Halobacteriales. Int J Syst Bacteriol 47, 233-238.

Ross, H. M., Grant, W. D. \& Harris, J. E. (1985). Lipids in archaeabacterial taxonomy. In Chemical Methods in Bacterial Systematics, pp. 289-299. Edited by M. Goodfellow \& D. E. Minnikin. London: Academic Press.

Saitou, N. \& Nei, M. (1987). The neighbor-joining method: a new method for reconstructing phylogenetic trees. Mol Biol Evol 4, 406-425.

Seghal, S. N. \& Gibbons, N. E. (1960). Effect of some metal ions on the growth of Halobacterium cutirubrum. Can J Microbiol 6, $165-169$.

Skerman, V. B. D., McGowan, V. \& Sneath, P. H. A. (editors) (1980). Approved lists of bacterial names. Int J Syst Bacteriol 30, 225-420.

Spurr, A. R. (1969). A low-viscosity epoxy resin embedding medium for electron microscopy. J Ultrastruct Res 26, 31-43.

Stan-Lotter, H., McGenity, T. J., Legat, A., Denner, E. B. M., Glaser, K., Stetter, K. O. \& Wanner, G. (1999). Very similar strains of Halococcus salifodinae are found in geographically separated PermoTriassic salt deposits. Microbiology 145, 3565-3574.

Stan-Lotter, H., Pfaffenhuemer, M., Legat, A., Busse, H.-J., Radax, C. \& Gruber, C. (2002). Halococcus dombrowskii sp. nov., an archaeal isolate from a Permian alpine salt deposit. Int J Syst Evol Microbiol 52, 1807-1814.

Thompson, J. D., Gibson, T. J., Plewniak, K., Jeanmougin, F. \& Higgins, D. G. (1997). The CLUSTAL_X windows interface: flexible strategies for multiple sequence alignment aided by quality analysis tools. Nucleic Acids Res 25, 4876-4882.

Tian, X. Y., Xu, Y. \& Liu, H. C. (1997). A new species of Natronobacterium. Wei Sheng Wu Xue Bao 37, 1-6 (in Chinese).

Tindall, B. J. (1990). A comparative study of the lipid composition of Halobacterium saccharovorum from various sources. Syst Appl Microbiol 13, 128-130.

Wainø, M., Tindall, B. J. \& Ingvorsen, K. (2000). Halorhabdus utahensis gen. nov., sp. nov., an aerobic, extremely halophilic member of the Archaea from Great Salt Lake, Utah. Int J Syst Evol Microbiol 50, 183-190.

Wang, Z., Xu, Y. \& Zhou, P. (2000). Taxonomy of a new species of haloalkalophilic archaeon. Wei Sheng Wu Xue Bao 40, 115-120 (in Chinese). 